\begin{tabular}{|l|l|l|}
\hline \multicolumn{2}{|c|}{ PublisherInfo } \\
\hline \hline PublisherName & $:$ & BioMed Central \\
\hline \hline PublisherLocation & $:$ & London \\
\hline \hline PublisherImprintName & $:$ & BioMed Central \\
\hline \hline
\end{tabular}

\title{
The future's bright, the future's online
}

\begin{tabular}{|l|l|l||}
\hline \multicolumn{2}{|c|}{ ArticleInfo } \\
\hline \hline ArticleID & $:$ & 4232 \\
\hline \hline ArticleDOI & $:$ & $10.1186 /$ gb-spotlight-20011023-02 \\
\hline \hline ArticleCitationID & $:$ & spotlight-20011023-02 \\
\hline \hline ArticleSequenceNumber & $:$ & 303 \\
\hline \hline ArticleCategory & $:$ & Research news \\
\hline ArticleFirstPage & $:$ & 1 \\
\hline \hline ArticleLastPage & $:$ & 4 \\
\hline \hline & $:$ & RegistrationDate : 2001-10-23 \\
ArticleHistory & $:$ & OnlineDate \\
\hline \hline ArticleCopyright & $:$ & BioMed Central Ltd2001 -10-23 \\
\hline \hline ArticleGrants & $:$ & \\
\hline \hline ArticleContext & $:$ & 130592211 \\
\hline \hline
\end{tabular}




\section{Helen Gavaghan}

Email: gavers@supanet.com

On 8 October 200140 members of the editorial board of The Journal of Machine Learning (JML) published by Kluwers, announced in an email to the scientific community they were throwing their academic seniority behind an alternative, electronic publishing enterprise The Journal of Machine Learning Research(JMLR).

Founded in the spring of 2000 by Louise Pack Kaelbling, Professor of Computer Science and Engineering at Massachusetts Institute of Technology (MIT), JMLR makes its research papers freely available on the web. For archiving purposes, MIT Press is to publish a hard copy version, which will be made available on a not-for-profit basis.

The move sends a powerful message to tenure track committees that, though the journal is new and does not have the academic record of $J M L$, publication in $J M L R$ should be assessed on the basis that it has the backing of a substantial portion of the editorial board that contributed to the reputation of $J M L$.

By releasing their announcement to the machine learning community by email, the 40 machine learning scientists also turned up the temperature on what is already one of the hottest topics concerning the conduct of science, namely the question of how scientists can most effectively review, register, disseminate and archive the knowledge gleaned during their work in this age of email and the Internet.

Before making their move, $J M L$ 's editorial board experienced several years of increasing frustration in their efforts to persuade Kluwers to listen to concerns.

At stake were a number of increasingly common areas of disagreement. Some, like how many pages the publisher budgets per year for the publication, can seem insignificant to the general public, but they go to the heart of the practice of science and can prevent important breakthroughs from being scrutinised in a timely manner.

"Machine learning is a fast moving field and papers that had already spent several months going through peer review were sitting for additional months in a pile waiting to be published because we did not have enough pages and could not guarantee to the publishers that we could sustain a higher page count," says Robert Holte, $J M L$ 's executive editor (a scientist, not a representative of Kluwers) and a Professor at the University of Alberta. "By the time they hit peoples' desks they could be out of date."

For scientists working in the world of machine learning there is particular irony in the fact that the latest findings did not reach the research community because they had not been printed.

Despite the frustration, Holte and a few colleagues have decided to stay with $J M L$ until it is clear how $J M L R$ will work in practice. So far it has published only 14 papers. But it has good prospects. "The people moving to $J M L R$ are the best on the field," says Holte, "and will be sorely missed. I'd have them back tomorrow."

But the points of contention between the board and Kluwers are deep and of long standing. They include questions of copyright, the price of journal subscriptions - particularly to institutions - and open access to electronic versions of the papers. 
During the past few months Kluwers has made some concessions. In July 2001 they agreed that publications would be freely accessible on the company web site until they were published, thus ensuring that research finds reached the community even though the printed version was not available. Then late last week they made copyright concessions by allowing scientists to post their papers on their homepages.

But these moves have proved to be too little too late, and JMLR is now being boosted by the support of most of $J M L$ 's editorial board. The new journal's policy is to turn papers around within six weeks (though the board will need to evaluate a balance between quality of review and turn around time).

$J M L R$ has unrestricted electronic access to the papers, authors will retain a large portion of copyright and the hard copy version of the journal will be available on a not-for-rofit basis.

This publishing model was established in 1992 by the Journal of Artificial Intelligence Research (JAIR), and it is one that Holte drew to Kluwer's attention more than two years ago when it was apparent that frustration was mounting among the scientists on the editorial board.

Kaelbling, the first of $J M L$ 's editorial board to resign two years ago, says she played with several ideas before settling on the JAIR model. Some she may yet put into practice. "For example, you could have a seal of approval that would be given to a paper by a group of experts in the field irrespective of where the research was published." She likens this idea to a scientific version of The New York Review of Books.

Certainly many different publishing models are possible. "We're not suggesting that one size fits all", says Michael Jordan, Professor of Electrical Engineering and Computer Science at the University of California, Berkeley and the instigator of the letter sent to the machine learning community last week, "At JMLR we received only a few hundred papers a year (Holte estimates 150) and we could assess those."

By contrast some of the larger journals covering a broader range of topics receive orders of magnitude more. Nature, for example, receives 10000 submissions for peer reviewed sections of the journal, and these are screened by 26 subject editors, who return $60 \%$ and forward $40 \%$ for peer review.

Whichever models of publishing the scientific community eventually settles on - all electronic, a mixture of paper and electronic, unfettered access or a partnership between commercial and academic publishing - the debate is far from abstruse. But it is increasingly obvious that publishers will need to listen to the scientific community, which plays a significant role in maintaining the standards of their product.

Kaelbling was initially motivated because she found it offensive that the editorial board were doing the work that gave the journal its quality whilst the publishers made a profit but a backlog of unpublished research built up. From last week's letter it seems she is not alone in this view.

Given the profound legal and ethical implications of modern science - from artificial intelligence to stem cell research and cloning - and that is funded by billions of dollars of tax payers money spent annually by governments around the world, the question of what science is published, when and how has relevance to more than the scientific community alone. 
Helen Gavaghan (gavers@supanet.com)

\section{References}

1. Journal of Machine Learning, [http://www.wkap.nl/journals/jml]

2. Kluwer, [http://www.wkap.nl/]

3. Journal of Machine Learning Research, [http://www.ai.mit.edu/projects/jmlr/]

4. Massachusetts Institute of Technology, [http://web.mit.edu/]

5. MIT Press, [http://mitpress.mit.edu/main/home/]

6. University of Alberta, [http://www.ualberta.ca/]

7. Journal of Artificial Intelligence Research, [http://www.cs.washington.edu/research/jair/home.html]

8. The New York Review of Books, [http://www.nybooks.com/]

9. University of California, Berkeley, [http://www.berkeley.edu/]

10. Nature, [http://www.nature.com] 